\title{
Medicine, Health and Economic Development: Promoting Spa and Seaside Resorts in Scotland c. $1750-1830$
}

\author{
ALASTAIR DURIE*
}

It is now fashionable for persons of all ranks to plunge into the sea, and drink the mineral waters ...

In 1769 the Edinburgh-trained physician, Dr William Buchan, produced the first edition of his Domestic medicine, which was to be a best-seller over the next thirty years. Edition after edition followed, nineteen in all in Britain, each of 5000 to 7000 copies. ${ }^{2}$ Pirated in America, translated into every language in Europe, recognized by the Empress of Russia, Domestic medicine made Buchan's name familiar in many a household in Scotland and beyond, no mean achievement for someone whom even his friends thought more fond of the coffee house than consultation, of prattle than practice. Buchan was a medical journalist, who revised the text from edition to edition to take account of the latest changes in medical practice; the 1772 Philadelphia edition incorporated a digest of a dissertation on the gout; the 1802 version included a section on the introduction of vaccination. It is highly significant, therefore, that Buchan added to the ninth edition published in 1786 an appendix in the form of a twenty page pamphlet, offering sensible advice about when and for which conditions it would be beneficial to bathe, at a bath, or in a river, or at the seaside; or to drink the mineral waters at a spa such as Harrogate in England or Moffat in Scotland. ${ }^{3}$ His son, a medical practitioner resident in London, was to follow in his father's

* Alastair Durie, PhD, Centre for the History of Medicine, Department of Economic and Social History, The University of Glasgow, 5 University Gardens, Glasgow G12 8QQ.

An early version of this paper was given at a day symposium, 'Scottish Medicine; Knowledge and Practice in the Making, c. 1730-1830', held at the Wellcome Trust Centre for the History of Medicine at University College London on 28 March 2001. I am grateful for a number of comments and suggestions received, including those of the referees, and also to the Library staff of the Royal College of Physicians in Glasgow, and to the Archivist of Dundee City.

${ }^{1}$ Dr William Buchan, Cautions concerning cold bathing and drinking the mineral waters, London and Edinburgh, A Strachan, T Cadell, J Balfour, and W Creech, 1786, p. 5.

${ }^{2}$ William Buchan, Domestic medicine, or, the family physician: being an attempt to render the medical art more generally useful by shewing people what is in their own power both with respect to the prevention and cure of diseases. Chiefly calculated to recommend a proper attention to regimen and simple medicines, Edinburgh, Balfour, Auld and Smellie, 1769. To the 1772 edition, published in Philadelphia by John Dunlap for $\mathbf{R}$ Aitken, was added: Dr Cadogan's dissertation on the gout.

${ }^{3}$ Buchan, op. cit., note 1 above; the full title of the 1786 edition of his book was Domestic medicine; or, $A$ treatise on the prevention and cure of diseases by regimen and simple medicine, London, A Strahan \& T Cadell. 


\section{Alastair Durie}

footsteps as a medical writer, and, responding to the "tide of fashion", himself wrote a guide to sea-bathing. ${ }^{4}$

"Taking the waters" at a spa was a long-established practice of proven popularity, but sea-bathing and salt-water therapy had more recently arrived on the scene, and was the subject of considerable contemporary debate as to its virtues and dangers. In England, sea-bathing had been under consideration by the medical profession for some period, thanks to Sir John Floyer's History of cold bathing. First published in 1702 , it was in its fifth edition within twenty years and began the process of converting sea-bathing from an eccentricity into a mainstream therapeutic weapon. Others followed suit. Dr Richard Frewin at Southampton showed the virtues of the seacure, and the treatise of the Sussex physician, Richard Russell, on the use of sea-water De tabe glandulari (or A dissertation on the use of sea-water in diseases of the glands) met and fed a growing demand in the $1750 \mathrm{~s},{ }^{5}$ and set him up in a highly profitable practice at Brighton. ${ }^{6}$ Russell, it may be noted, was no single string enthusiast: he also promoted a nearby chalybeate spring. As with all "near panaceas", ${ }^{7}$ experience was to temper enthusiasm. While some health-seekers benefited greatly, as enthusiasts testified, others did not. It might be due to a failure to follow up the cure with appropriate aftercare-some recommended that on return from the sea use be made of indoor baths, ${ }^{8}$ cold or warm - or it might be too much or the wrong treatment at the seaside. In a well-publicized case, a sufferer from gout had, according to the London Chronicle, nearly killed himself at Margate by "unadvisedly bathing in the sea at an improper period", or so a local surgeon said." Medical men were unhappy with self-medication at any time, and indeed not at all enthused by the way in which Buchan made medicine accessible to the untutored, although he did stress the need to take professional advice. Nevertheless, the subtitle that he added, "to show people what is in their own power both with respect to the prevention and cure of diseases", seemed rather to undermine his own profession's privileged place. While it made him the idol of nurses and midwives, he faced the hostility and dislike of the least liberal part of the faculty, or so his obituary said. ${ }^{10}$

That Buchan's attention was turned in the mid-1780s to these aspects of health is, however, important and indicative of the way in which by the later eighteenth century both spas and sea-water bathing in Scotland had become part of the agenda of those wishing either to become or stay healthy. And if Buchan could make money from his medical writing, others could look to the possibilities of profit from the pursuit of health at the seaside or at a spa. The latter was already a proven money

\footnotetext{
${ }^{4}$ A P Buchan, $A$ treatise on sea bathing: with reinarks on the use of the warm bath, 2nd ed., London, T Cadell and W Davies, 1810.

${ }^{5}$ Alain Corbin, The lure of the sea: the ' 'iscovery of the seaside in the western world, i750-1840, transl. Jocelyn Phelps, London, Polity Press, 1995, pp. 65-71.

${ }^{6}$ See Laura Cunningham, 'Dr. Richard Russell: the seaside and the therapeutics of sea water', University of Glasgow, History of Medicine Dissertation, April 1997.
}

\footnotetext{
${ }^{7}$ John $\mathrm{K}$ Walton, The English seaside resort: $a$ social history, 1750-1914, Leicester University Press, 1983, p. 11.

${ }^{8}$ 'Useful hints concerning sea-bathing', The Scots Magazine, Sept. 1786, p. 423.

${ }^{9}$ Cited in Buchan, op. cit., note 1 above, p. 13.

10 'Obituary, with anecdotes of Dr William Buchan', Gentleman's Magazine, March 1805, 75 : 287-8.
} 
spinner on the Continent and in England, and some ventures had been made in Scotland; but the seaside offered a new dimension for development to landowners, local merchants and others. South of the Border, as Peter Borsay and Phyllis Hembry have shown, ${ }^{11}$ this was a period of considerable development, and equal potential existed in Scotland as the transformation of the Scottish economy led to the creation of growing numbers of leisured people with surplus income and a desire for health. The landowning élite demonstrated a particular commitment to the development of their localities through the promotion of planned villages, of which a central focus was usually textiles, as at New Leeds. Some, however, must have been aware of the potential of spas to generate wealth and employment ${ }^{12}$ as a fair number had themselves visited either Continental resorts or English ones such as Bath, Buxton or Harrogate. As early as 1730, Defoe commented that amongst the company at Scarborough, he had found a fair number who had come from Scotland. ${ }^{13}$ Spa treatments took time, and required weeks of residence, and, for those not too ill, the need to add entertainment and amusement to their accommodation and therapeutic services offered further opportunities to generate revenue. The growing interest in the seaside also held out a promising source of income.

This is the territory which this article seeks to explore: the why, when and how of development in Scotland. It does not address the question of which regimes and waters were actually of therapeutic value, or enter the hotly contested debate on how scientific the medical investigations were. By way of context, it should be noted that there are no good contemporary or current studies of the spas movement or of the seaside in Scotland, though there is a mass of minor literature and the study of healing wells is certainly much in vogue. ${ }^{14}$ There is, however, nothing equivalent to A B Granville's The spas of England, published in 1841, a three part sequel to his Spas of Germany, which surveys some thirty-six leading mineral spring resorts in England, or even Alexander Knox's comprehensive Survey of Irish spas, which appeared in 1845. Nor has anything like the same academic attention been given to the rise of the Scottish seaside as has been done for England by John Walton or John Travis. ${ }^{15}$ When examining the rise of significant localities in Scotland, a central element in the argument is that the voice of medical or scientific authority was much more important for a spa resort than was true for its counterpart at the coast. In authenticating the claim of any waters to medical virtue (a much-used word), no spa could progress to resort status unless "proofed" by an analysis. By contrast, the seaside resort needed no such particular stamp of approval. What mattered was the

\footnotetext{
${ }^{11}$ Peter Borsay, 'Health and leisure resorts $1700-1840$ ', in P Clark (ed.), The Cambridge urban history of Britain, vol. 2, 1540-1840, 3 vols, Cambridge University Press, 2000, pp. 775-803; and P Hembry, The English spa 1560-1815, London, Athlone Press, 1990.

${ }^{12}$ See M L Parry and T R Slater (eds), The making of the Scottish countryside, London, Croom Helm, 1980. In his essay on the 'The planned villages', Douglas Lockhart does not identify any apparently founded for health.
}

\footnotetext{
${ }^{13} \mathrm{D}$ Defoe, $A$ tour through the whole island of Great Britain, 2 vols, London, Dent, 1928, vol. 2, p. 247.

${ }^{14}$ For example, see R and F Morris, Scottish healing wells, Sandy, Alethea Press, 1982.

${ }^{15}$ Walton, op. cit., note 7 above; John F

Travis, The rise of the Devon resorts, 1750-1900, University of Exeter Press, 1993.
} 
general endorsement of science and medicine given to salt-water treatments and seabathing. A coastal resort might make claims for the superiority of its local climate, beaches, amenities, and accommodation, but not that its salt water, if sea water, was intrinsically more therapeutic. The level of salinity, in which iodine and bromine were supposed to be the active agents, did matter, as did the calibre of the sea air or ozone. ${ }^{16}$ Watering places up an estuary or firth were handicapped in curative terms by the dilution of the salt by fresh water, as well as by increasing urban pollution in the case of locations close to Glasgow or to Edinburgh.

\section{The Discovery of the Scottish Seaside}

Unlike northern England, as John Walton has described, there seems to have been no tradition of popular interest in the seaside in Scotland other than an occasional reference to sea-bathing in the north of Scotland as a cure for the common itch. ${ }^{17}$ It was the upper classes who found their way to the sea first, prompted by southern fashion and steered by their physicians for therapeutic purposes, a practice that spread north slowly in the later eighteenth century. By the 1770s, some Edinburgh physicians were already recommending sea-bathing to their clients, ${ }^{18}$ both for adults and particularly for delicate children. The young and rather sickly Walter Scott was sent to Prestonpans for the summer of 1778 to take advantage of the sea bathing. Once tried, the pattern gained acceptance and quite a number of Scottish coastal resorts were beginning to benefit on a modest scale by the end of the century. By contrast to the endorsement required for a spa, once the therapeutic value of seabathing had been established, individual resorts needed no further authentication. Of course, the provision of amenities helped popularization: baths, bathing machines, walks and wet weather amusements. The presence (or absence) of bathing machines was a sure indicator of the level of development at a coastal resort. When Elizabeth Diggle travelled north to Scotland in 1788, she made an excursion en route to Tynemouth, where she found a charming retired bay entirely suitable for bathing. As it was only late April, it was too early in the season for "the machines to have come down [to the beach]" ${ }^{19}$ But at least Tynemouth had these. At that time, although bathing machines had been available at the leading English coastal resorts since the 1750s (or even earlier in the case of Scarborough), ${ }^{20}$ not one was to be found at any coastal resort in Scotland, and it was 1795 before even Portobello-perhaps

\footnotetext{
${ }^{16}$ A B Granville, Spas of England and principal sea-bathing places (1841), 2 vols, Bath, Adams \& Dart, 1971 (reprint), vol. 2, pp. 5-9.

${ }^{17}$ Walton, op. cit., note 7 above, pp. 10-11; A P Buchan, op. cit., note 4 above, pp. 194-5.

${ }^{18}$ See Papers of Dr John Hope: 'Medical history of Captain Keith Elphinstone, 13 August 1783', which recommends sea-bathing and the use of mercury, National Archives of Scotland, GD 253/143/1.
}

${ }^{19}$ Elizabeth Diggle notebook; letter dated April 20, 1788 from Newcastle, Glasgow University Library, Accession number 4311.

${ }^{20}$ Cunningham, op. cit., note 6 above, p. 52, citing Sue Farrant, Georgian Brighton, 1740 to 1820 , Brighton, Centre for Continuing Education, University of Sussex, 1980, p. 15. 


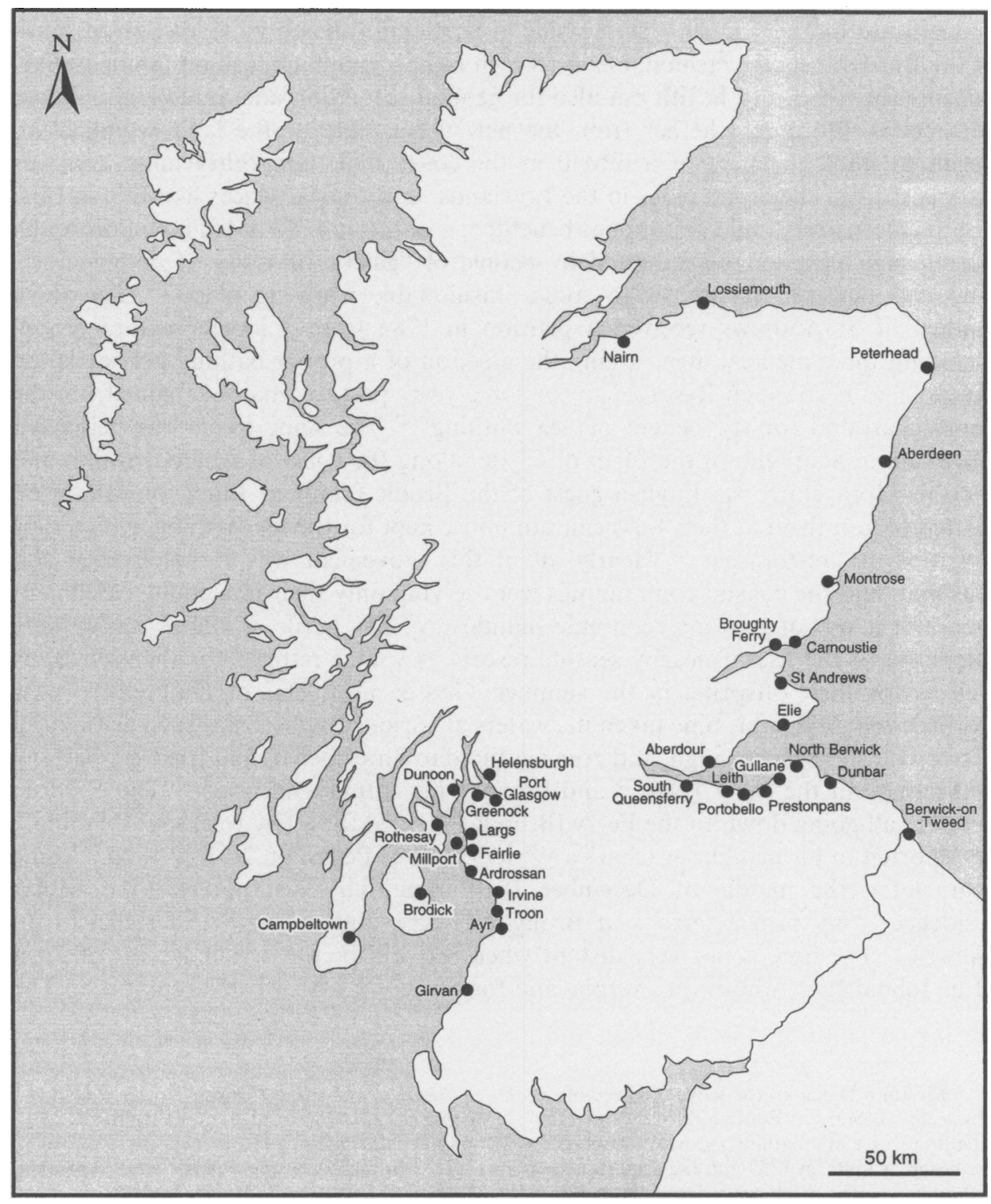

Figure 1: Seaside resorts of Scotland. 


\section{Alastair Durie}

the most popular Scottish beach resort of the time, thanks to its proximity to Edinburgh - had them regularly available for hire. ${ }^{21}$

The initial interest in the seaside may have been created by changing medical perceptions, but very quickly the seaside in Scotland, following the lead given south of the Border, became fashionable in its own right for individuals and families alike, not just for reasons of health but also for general recreation and amusement. Those who could afford it, whether from the new urban élite or the landowning class, began to think in terms of a retreat at the coast. This temporary migration was strongest from the larger cities in the Lowlands, and coastal places like Elie in Fife, South Queensferry and Prestonpans benefited; a visitor in 1793 noted how Edinburgh during high summer was deserted by people of "gaiety, of study or of business", who had betaken themselves to some "fashionable watering place". 22 The town council of St Andrews received a petition in 1784 from a local pressure group, including three medical men, urging the erection of a proper bathing house, as the burgh "had been much Resorted to for some years past, by many Persons from the country around for the benefit of Sea Bathing". ${ }^{23}$ The same trend was being felt elsewhere in Scotland: in the Firth of Clyde, along the coast of Aberdeenshire, and even in Morayshire. An English guest of the Brodie family at Elgin found himself invited to join them at their Lossiemouth house kept for the sea-bathing, which they regarded as "restorative". ${ }^{24}$ Nearly all of this movement was short-distance and seasonal, and the coastal communities were serving only their immediate catchment area, but it was of growing economic significance. The lairds of inland Angus were interested in the use of nearby seaside resorts as winter retreats for themselves, as well as for their offspring in the summer. George Dempster of Dunnichen (near Forfar), who had in his time taken the waters at various English spas such as Buxton, Harrogate and Scarborough, and even ventured to Strathpeffer, first tried sea-bathing at Margate in the early $1780 \mathrm{~s},{ }^{25}$ and brought his enthusiasm north. "The children here are all going down to the Ferry [Broughty Ferry] for a few weeks sea-bathing", he reported to his neighbour Charles Wedderburn of Peasie on 30 July $1800 .{ }^{26}$ Some years later, the middle of December 1810 found him just moved to a winter residence- "my pied à terre"-at Broughty Ferry, and urging Wedderburn to do likewise. "The time is not very distant when this will be the winter Resort of most of us Inland Lairds both for exercise and for Society. I wish I could tempt you. The

\footnotetext{
${ }^{21} \mathrm{Mr}$ John Dallas of the Royal College of Physicians' Library at Edinburgh, has drawn my attention to a static bathing caravan stationed on the beach at Leith in 1750 and the appearance of orthodox wheeled machines a decade later.

${ }^{22} \mathrm{R}$ Heron, Observations made in a journey through the western counties of Scotland, 2 vols, Perth, R Morison, 1793, vol. 1, p. 9.

${ }^{23}$ Eric Simpson, St Andrews in old postcards, Zaltbommel, European Library, 2001, p. 1.

${ }^{24} \mathrm{R}$ L Willis, Journal of a tour from London to Elgin, made about 1790, Edinburgh, Thomson, 1897, p. 72 .
}

\footnotetext{
${ }^{25}$ Letters of George Dempster to Sir Adam Fergusson, 1756-1813, ed. James Fergusson, London, Macmillan, 1934, p. 111; dated 27 Sept. 1782. "I brought my wife and her sister down to Margate to bathe for both their healths."

${ }^{26}$ Dundee City Archives, GD 131, Box 6, bundle 15. See also (ibid.) Mr Maxwell of Dundee to Charles Wedderburn, April 1823; "We intend spending the summer months at Broughty Ferry where I have taken a house for the Season. I think the Children's constitutions may be benefited by the Sea Air \& Sea bathing."
} 


\section{Spa and Seaside Resorts in Scotland c. 1750-1830}

place is full of furnished lodgings ... mine costs me $£ 77 \mathrm{~s}$ for the season." ${ }^{27}$ Dempster was a consistent advocate of the east coast. In April 1812, he was again pressing his campaign, but this time with St Andrews in mind.

The whole French nobles of the Provinces report to their Pied-à-Terre in the capitals of their provinces in the dead of winter, and enjoy pleasant and costless society there ... I am going to prescribe for you, and Mrs Rattray something that would preserve her health, \& restore yours ... The air of Catlaw is too sharp for five months in winter. It cannot agree with an Indian, even a Coventry Constitution. Give me a commission to look out for a pied à terre for you in St Andrews for Dec, Jan, Feb, March nay even April. We call it a furnished lodging, not a house. You have the use of a kitchen of the landlady for cooking and cleaning ... the society excellent $\&$ cheap, Tea $\&$ cards, the custom of the place; forenoon calls, \& walks, numbers of well-bred people at their Ease, every topic of conversation, except about acquiring wealth.... Ingenious lectures on chemistry, natural philosophy \& astronomy, churches with famous preachers $\ldots{ }^{28}$

But wintering on the east coast did not catch on, although some resorts in the milder west such as Rothesay-otherwise known as the Torquay of Scotland-had more success in attracting invalids. Sea-bathing or salt-water dipping was what was firmly established by the beginning of the nineteenth century, as was the seaside as a place for recreation, health and education. Moreover, its appeal had changed and broadened: it was not just for invalids or convalescents, nor just for the upper classes, nor even as part of a lengthy holiday. More and more went out from the big cities for a weekend or even for a morning dip if a reasonable beach were not too far distant. And the change occurred relatively quickly: within perhaps a single decade of the 1780s. The first mention of sea-bathing at Aberdeen, for example, comes in the local newspaper, the Aberdeen Journal, in October 1789. As part of the correspondent's assertion that no town in Scotland had greater advantages as a watering place, he refers to "an excellent beach, very readily accessible, [which] renders it peculiarly convenient for salt water bathers." ${ }^{29}$ The Glasgow merchant, Adam Bald, kept a journal of his holiday excursions in Scotland between 1790 and 1833. Many of the earlier sorties were to the Firth of Clyde, and, in the preface to his account of a "ten days ramble to the Sea Coast" of Cowal and Bute in July 1791 , he drew attention to the change in the kind and condition of the visitors to be met.

It was the custom for valetudinarians in the inland parts of the country to repair for the summer to the Sea Coast, with the expectation of fortifying their constitutions from the Morbifick influence of a winter blast. For this purpose every spot on the seashore was crowded with the diseased and emaciated part of mankind, but now the scene is dramatically changed [my italics]. Instead of the cadaverous looking sojourner, you meet now the plump and jolly ... full of health and spirits, whilst the sickly race are confined to their gloomy chambers,

\footnotetext{
${ }^{27}$ George Dempster, 16 Dec. 1810, Dundee City Archives, GD 131, Box 6, bundle 15.

${ }^{28}$ George Dempster, 24 April 1812, Dundee City Archives, GD 131, Box 6, bundle 15.
}

\author{
${ }^{29}$ Aberdeen Journal, 5 Oct. 1789, 'Domestic \\ occurrences', p. 3.
}




\section{Alastair Durie}

driven from their summer retreats by the intrusion of the gay votaries of pleasure lured to these marine haunts $\ldots{ }^{30}$

The enthusiasm for the seaside, for sea-bathing and the delights of the seashore, which Bald dubbed "the Saltwater Mania", was initiated by the recognition of the therapeutic value of cold water bathing, which medical authorities did much to establish and endorse. ${ }^{31}$ As William Saunders remarked in 1800 , "the sea is by far the most frequented of all our medical baths." 32 But the rapid growth in the late eighteenth century was the result of a takeover by a much wider constituency in the name of health and pleasure, in which the medical profession played little or no part. What counted thereafter in the development of Scottish seaside resorts, greatly assisted by the coming of the paddle steamers, ${ }^{33}$ was the local enterprise of landowners or other commercial interests in the provision of accommodation, baths, hot and cold, libraries and the other amenities that made a locality attractive.

\section{The Beginnings of a Spas movement in Scotland}

If the seaside was a relatively new arena of opportunity, the roots of interest in spas and watering places in Scotland went back much further. It was unfortunately true that Scotland could only look enviously at the long-established wealth and prosperity of Bath, or the rising momentum from the 1730 s of inland spas such as Tunbridge Wells, Epsom, and Harrogate, or the advances being made from midcentury at Brighton and Scarborough, where sea-treatments and mineral spring therapies complemented each other. There was no surge of spa development in Scotland prior to the mid-eighteenth century on the scale of that in England. Besides improvements at Bath, Tunbridge and other existing spas, Hembry identifies some thirty-four new spa foundations between 1700 and 1749, including Cheltenham and Gilsland, and more every decade thereafter. ${ }^{34}$ But there was certainly some interest north of the Border. Already firmly on the health map was Moffat, a destination for the upper classes of Edinburgh since the seventeenth century. Other spas of growing significance included Pitkeathly (near Perth), Dunblane, Pannanich (near Ballater), St Fillan's (near Comrie) and Innerleithan or St Ronan's (made famous beyond its actual patronage by Walter Scott), St Bernard's Well at Stockbridge in Edinburgh (to which William Cullen sent some of his patients), ${ }^{35}$ to name but a few. There were occasional locations that successfully combined drinking spa water with sea-bathing, such as Peterhead and Brow on the Solway near Dumfries, which the

\footnotetext{
30 'Journal of Adam Bald, no. 5', Mitchell Library: Glasgow City Archives; TD 1916. Bald concludes this section: "naught now will satisfy either married or unmarried, or the aged and young but a trip for the summer to the coast".

${ }^{31}$ On cold water treatment, see John $\mathbf{M}$ Forrester, 'The origins and fate of James Currie's cold water treatment for fever', Med. Hist., 2000, 44: $57-74$.

${ }^{32}$ William Saunders, $A$ treatise on the chemical history of medical powers of the most celebrated
}

\author{
mineral waters... To which are added, \\ observations on the use of cold and warm bathing, \\ London, William Phillips, 1800, p. 221. \\ ${ }^{33}$ See A J Durie, Scotland for the holidays: \\ tourism in Scotland 1780-1939, East Linton, \\ Tuckwell Press, 2002, ch. 3, 'To the seaside'. \\ ${ }^{34}$ Hembry, op. cit., note 11 above, pp. 357-60. \\ ${ }^{35}$ See $\mathrm{J}$ Taylor, $A$ medical treatise on the \\ virtues of St Bernard's Well, illustrated with \\ selected cases, Edinburgh, W Creech and $\mathbf{J}$ \\ Ainslie, 1790.
}




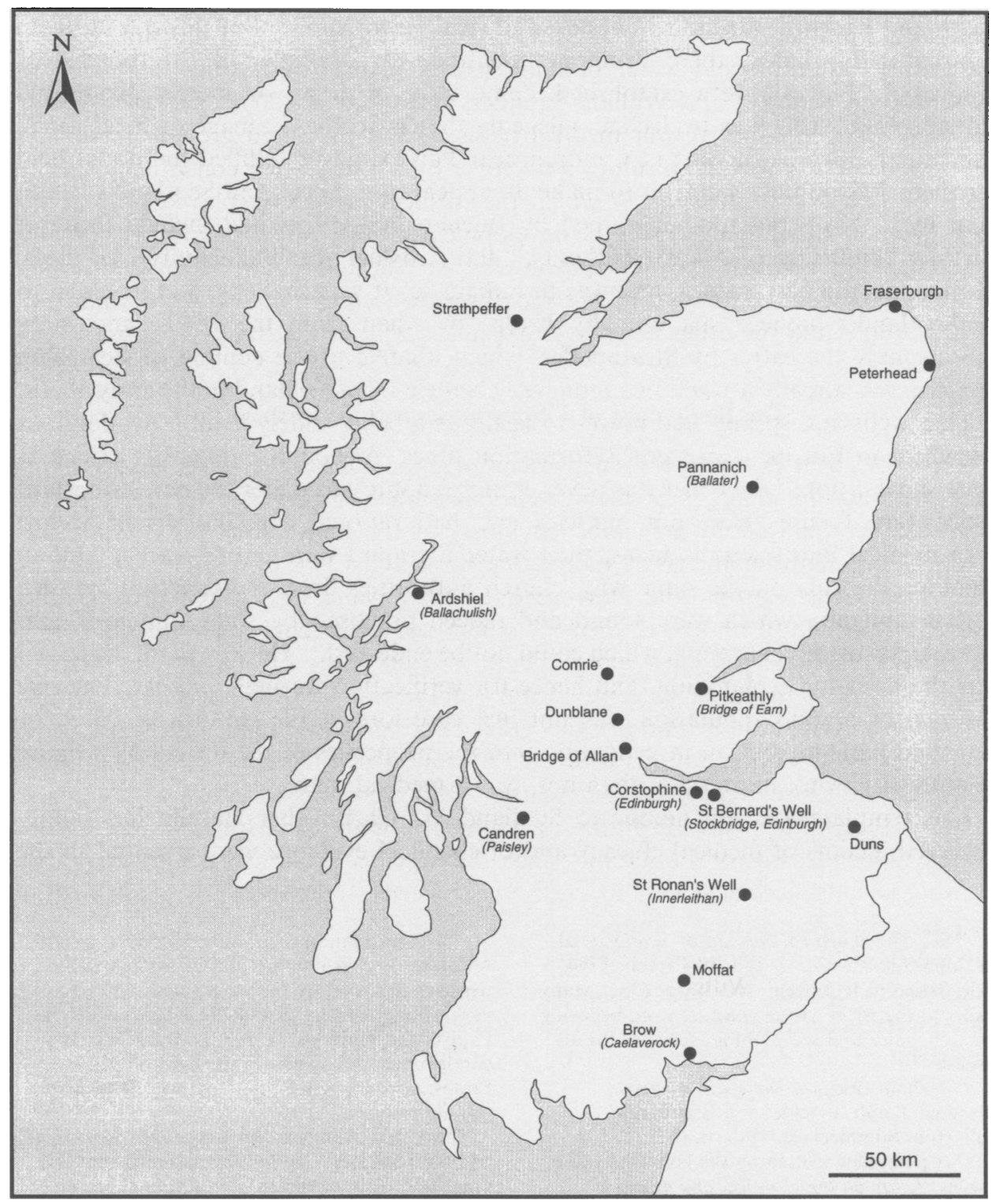

Figure 2: Spas of Scotland. 


\section{Alastair Durie}

terminally ill Robert Burns visited in the summer of $1796 .{ }^{36}$ Buchan's 1819 edition of Domestic medicine lists some thirty springs of significance, some chalybeate, others sulphur or seltzer, most of which had only a local clientele as, for example, those of Keith and Kirkurd, the latter "supposed to rival Harrogate". ${ }^{37}$ But this is a far from comprehensive index, there being no mention, for example, of Strathpeffer or Pannanich. Not all were established: some were in decay or merely promising. Corstorphine's role was in decline, allegedly thanks to the drainage of local fields, and others, such as the one at Candren near Paisley, never fulfilled the hopes held for them..$^{38} \mathrm{~A}$ number were yet to make an appearance. Springs in Scotland's health map by $c$. 1840 , but not mentioned by Buchan in 1819, would include those at Airthrey (or Bridge of Allan), Rothesay, ${ }^{39}$ and Ardshiel near Ballachulish. Of these, Moffat was the best known, and was to remain so. It was challenged in its claim to be Scotland's premier spa only by Bridge of Allan from the $1840 \mathrm{~s}$, and more convincingly thereafter by Strathpeffer, which, thanks to the coming of steamship services, was already attracting a moneyed clientele from England in the early 1830s.

That wells and springs had power to heal was a belief widely held in Scotland, as elsewhere in Europe, since pre-Reformation times. Although dubbed by critics as mere superstition, ${ }^{40}$ the belief was never entirely suppressed under the new Protestant order. But if cures were not miracles and had rational explanations in accord with medical and scientific ideas, then water therapies were entirely acceptable in theological terms. In the same way, church authorities drew a distinction between herbal remedies, which were sound and indeed practised by some ministers, and mere superstitious charming, which could not be endorsed. ${ }^{41}$ The key point, however, was the need for explanation, and hence for verification through enquiry. The sine qua non of a spa's reputation was not just case lore in the persons of cured or benefited patients, but an investigation into the properties of the waters by a figure of authority, who, more often than not, was a medical man.

This template was not unique to Scotland. As Christopher Hamlin has rightly observed, claims of medical efficacy and of chemical evidence were essential to the

\footnotetext{
${ }^{36}$ See The statistical account of Scotland, ed. Sir John Sinclair, Edinburgh, W Creech, 1794, 'The Parish of Ruthwell', vol. 10, p. 223: "Many resort to the Brow in the warm season, believing the well water and sea bathing, specifics for all diseases."

${ }^{37}$ William Buchan, Domestic medicine, Glasgow, Knull, Blackie; and Edinburgh, Fullarton, Sommerville, 1819, p. 683.

${ }^{38}$ A pamphlet written by the late Dr Lyall of Paisley, Essay on the chemical and medical qualities of Candren Well, Renfrewshire, Paisley, J Neilson, 1813, strongly recommended its water as an aperient and corrective.

${ }^{39}$ The new statistical account of Scotland, vol. 5 Ayr, Bute, 15 vols, Edinburgh, William Blackwood, 1845, p. 99, stated that the spring at Bogany Point is "much visited by invalids and is exceedingly beneficial in cases of rheumatism".
}

\footnotetext{
${ }^{40} \mathrm{Cf}$. Buchan, op. cit., note 37 above, p. 681 . "Almost every parish has still its sainted well, which is regarded by the vulgar with a degree of veneration, not very distant from that, which in Papists and Hindoos we pity as degrading, and condemn as idolatrous ... the light of Protestantism has not been able wholly to dispel this superstition."

${ }^{41}$ Scottish Archives Network: www.scan.org.uk; 'Herbal remedies'. "It is often assumed that the practice of folk medicine by traditional healers was persecuted by the church ... However this may be too simplistic a summary. Church authorities often differentiated between herbal remedies and superstitious charming. Notes of herbal remedies provide evidence that ministers used local knowledge of herbs and cures to augment the medical training they received at university".
} 
conversion of a country spring to a commercial spa; they were essential as a precondition of development though not of themselves sufficient to guarantee success. ${ }^{42}$ In practice such reports, however well presented and documented, were not always above suspicion, but reliability mattered less than plausibility. It would have added greatly to the assessment process had the consultant's report occasionally been negative or unenthusiastic, but, unsurprisingly, no such document is known. There was always the temptation to talk up the virtues of a locality and its waters, if that was what was wanted; self-interest tended to taint objectivity. Location, access, amenities and patronage, were also necessary. In the promotion of a spa and its spring or springs, the package generally included an account of the discovery, which might be by someone of any station in life; all that was needed was sight, smell and taste. There then followed the assessment of an "expert" as to the efficacy of the waters, and a selection of cases treated successfully. Scott in his novel St Ronan's Well shows the accepted formula.

A fanciful lady of rank in the neighbourhood chanced to recover of some imaginary complaint by the use of a mineral well about a mile and a half from the village; a fashionable doctor was found to write an analysis of the healing waters, with a list of sundry cures; a speculative builder took land in feu, and erected lodging houses, shops and even streets. [My italics. $]^{43}$

Methods of water analysis were far from scientifically well developed, and when repeated the results were far from consistent. As John Macadam, himself a lecturer in chemistry and a professional analytical chemist, observed diplomatically in 1854 of the perplexing differences between Thomas Garnett's findings at Moffat in 1797 and Thomas Thomson's thirty years later, these might have been the result of changes in the water, rather than defective methods of analysis. ${ }^{44}$ Medical insiders tended to be suspicious of so-called scientific studies, as Buchan was himself. "One page of practical observations", he remarked, "is worth a whole volume of chemical analysis." ${ }^{45}$ But what mattered was whether a report was credible, not whether it was true, and for this it was essential that the reporter be someone of scientific or medical standing to whom the results could be rewarding in financial terms. It was no accident that Dr Francis Home, a newly qualified MD just returned from military service in Flanders, was asked by the Earl of Home in 1751 to analyse the qualities of the Duns spa waters located on his lordship's lands. These had only recently come to light, but already had something of a reputation for cure. Home, chosen on promise and connection, was to have a distinguished career, becoming in effect a house chemist to the Lothians' gentry; amongst his other commissions was an enquiry into linen bleaching for the Board of Trustees. At Duns he mixed medical

\footnotetext{
${ }^{42}$ Christopher Hamlin, 'Chemistry, medicine, and the legitimization of English spas, 1740-1840', in Roy Porter (ed.), The medical history of waters and spas, Med. Hist., Supplement No. 10, London, Wellcome Institue for the History of Medicine, 1990, pp. 67-81.

${ }^{43}$ Walter Scott, St Ronan's Well, London and New York, Henry Frowde, Oxford University Press, 1912, p. 10.
} 


\section{Alastair Durie}

observation with close examination of the waters, and the result of his research was a pamphlet entitled An essay on the contents and virtues of Dunse Spaw published in Edinburgh in 1751. Home found some case histories which were encouraging; for example, a boy with glandular problems who had tried the Corstorphine and Moffat waters with no success, was put right by a summer at Duns. Other afflictions that had been alleviated included cases of scurvy and skin complaints, as well as stone and gravel. Home was careful not to overstate the effects of the waters; they had had only mixed success in the treatment of chronic rheumatism. Cases of gout had scarcely been tried. What always made any Scottish spa's waters trustworthy was how similar they were to established English or Continental waters. Home's work was positive in endorsing that at Duns: he found the spring to be equivalent to the Tunbridge waters. Some forty years later the local parish minister referred with respect to the analysis carried out by Professor Home of Edinburgh. ${ }^{46}$ Yet, for all Home's standing, the spa failed to develop: authentication of the waters alone was not sufficient.

In 1822, an Episcopalian clergyman from Paisley, the Rev. W M Wade, published a guide to the watering and sea-bathing places of Scotland. ${ }^{47} \mathrm{His}$ is a valuable assessment of the various resorts in Lowland Scotland (though he did venture as far north as Fraserburgh) and of the situation in Scotland generally, which he considered to be lagging behind England in development and lacking in cultural life. The resorts, or so he said, "solicit not, unless in a very few cases, to the showy theatre, the gay assembly, the brilliant parade, or the dazzling repository of dress and decoration" ${ }^{48}$ Wade was careful to point out how resorts, spa and seaside, were developing and what they had on offer, giving particular praise to Leith with its numerous bathing machines ("conveniences as yet by far too rare at Scottish seaside watering places") and the "exceedingly complete Seafield Baths". ${ }^{49}$ But whereas in the context of the Scottish spas he gave real weight to various analyses of the mineral waters, cited in extenso, and whether they were chalybeate, sulphurous or saline, nothing comparable was given on the seaside resorts other than an occasional reference to the value of a good climate, sea air and water "in its most saline state, the objects of most importance to those who would either restore or confirm health". ${ }^{50}$ Wade went into very great detail about the spa waters at Moffat ("the Scottish Cheltenham"), Dunblane, and Pitkeathly ("the Scottish Harrogate"). When the subject first presented itself in the context of the Dunblane springs, Wade took the opportunity to explain from personal knowledge what was involved in the routine of taking the waters, and offered some gentle advice on how to get the best from the experience. If taking the water did good, some people reasoned, why not take as much as possible to accelerate the cure? This he counselled against:

Care should be taken to avoid the strange, though common error of gulping down immense quantities of water. We have ourselves beheld individuals swallowing, boasting, moreover, of

\footnotetext{
${ }^{46}$ The statistical account of Scotland, ed. Sir John Sinclair, Edinburgh, William Creech, 1792, 'The Parish of Dunse', vol. 4, pp. 379-80.

${ }^{47}$ W M Wade, Delineations, historical, topographical, and descriptive of the watering and
}

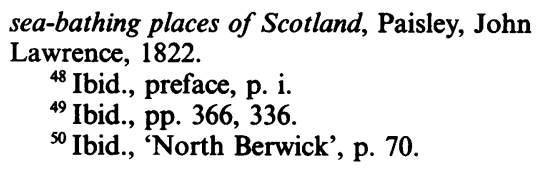


the feat, their tenth and even twelfth tumbler of fully half an English pint: but thus to oppress the stomach with a cold fluid can serve no good end. ${ }^{51}$

But Wade was careful to respect lines of demarcation. He was not a medical man himself, and did not wish to encroach on their province. People who were ill should drink of a mineral water only under the direction of a medical adviser. Wade attempted no evaluation of how the waters were beneficial, and indeed, for inclusion in a second edition, invited an essay on the nature, use and effects of mineral waters from a qualified practitioner. What he did do was to report what various investigations had found, including that of Dr Thomas Garnett on the Moffat springs. It is unfortunate that Wade did not cover some of the other Scottish spas, notably Strathpeffer, but the general point stands, what mattered to a spa was specific medical endorsement. It could not guarantee success, but without it, progress was very unlikely.

A contemporary letter, signed by "Etonensis" in the Gentleman's Magazine in 1787 insisted that there were only three Scottish spas of real significance: Peterhead, Pannanich and Moffat. "The resort to these places has, of late years, been frequent, and that too by persons of bon ton". 52 This was a short list which by its omissions would have annoyed those who, for instance, were devotees either of Pitkeathly ${ }^{53}$ or of Strathpeffer. The latter, given its northerly location, illustrates that if the calibre and reputation of waters was good enough, seekers after health were quite prepared to accept demanding travel to reach their treatment. Following Donald Monro's 1772 analysis of the well waters there, which concluded that they were at least equal, if not superior to the waters of Harrogate, ${ }^{54}$ there had been quite a surge in patronage, and the local factor had fanned interest by recording and publicizing two remarkable cures. The Board of Annexed Estates, a government body charged with administrating and developing the estates confiscated from leading Jacobite figures, were sufficiently persuaded to commission an estimate in 1777 for the laying out of a village, complete with inn, near the wells. ${ }^{55}$ In July 1795, George Dempster had joined a friend who was spending six weeks there, "drinking for his ugly leg Strathpeffer water", and claimed that a mere fortnight had renewed his age "like the eagle's" ${ }^{56}$ But "Etonensis" was either ignorant of, or indifferent to, its claims and clientele. For him, the favoured spa was Moffat, with its sulphurous well known for over 150 years, and the chalybeate spring discovered about forty years previously (in 1748) by John Williamson, a local farm tenant.

${ }^{51}$ Ibid., p. 158.

${ }^{52}$ Gentleman's Magazine, Aug. 1787, p. 171.

${ }^{53}$ On Pitkeathly, see 'An account of Pitkeathly House and the waters near it', The Scots Magazine, April 1812, pp. 243-6.

${ }^{54}$ Donald Monro, An account of the sulphureous mineral waters of Castle-Leod and Fairburn in the county of Ross; and of the salt purging water of Pitkeathly, in the county of Perth, published as a pamphlet in Edinburgh, 1772, and also in the Philosophical Transactions of the Royal Society.

${ }^{55}$ Eric Richards and Monica Clough, Cromartie: Highland life 1650-1914, Aberdeen University Press, 1989, p. 93.

${ }^{56}$ Letters of George Dempster, op. cit., note 25 above, p. 257. 


\section{Alastair Durie}

\section{Three Scottish Spas}

We now turn to a more detailed examination of the three named spas: Moffat, the longest established and best-known; Pannanich, an inland spa developed in the 1780s; and Peterhead, which combined both spa and seaside therapies. There is certainly some justice to the claim that Moffat was then, and remained, Scotland's premier spa. It could trace a long pedigree for the use of its waters, their significance and potential being first recognized in 1633, or so local lore asserted, by a Rachel Whyteford, an English bishop's daughter, who had recently settled in the locality after her marriage to a local laird, and was familiar with English spas. ${ }^{57}$ The well was first examined by Dr Matthew Mackail from Edinburgh in 1659 and his treatise, entitled Fons Moffetensis, was translated and published. By the mid-eighteenth century, Moffat was firmly established as a health resort, much patronized by the legal and landed profession during the summer vacation of the law courts at Edinburgh. Local heritors, especially the all-important Douglas family, did what they could to promote the town's development; funding the construction of local inns able to provide a better class of accommodation for a clientele of rank, and constructing paths and walks to the newly discovered Hartfell Springs, where a pavilion was provided. But there was a problem. If the waters were so effective, and medical endorsement and experience alike confirmed that was true- -"most wonderful cures have been effected by it" wrote the parish minister in $1791^{58}$ - then was access not to be free to all? But would not the better-off be deterred by sharing the facilities with the poor, who either found their own way there, or whose stay was subsidized by charitable trusts and funds? Did not the needy sick of all and any classes have equal rights? Perhaps they did, but not to private property, which the land around the spring heads was. The Marquis of Annandale had appointed keepers at the Well but John Clerk of Penecuik complained in 1748, "As the well is quite open night and day there is a number of diseased scrophulous [sic], leperous people lying about it and who seem to be watching for an opportunity to wash their sores unseen by the two keepers." ${ }^{59}$

There are a number of themes that a full study of the social challenges posed at health resorts could pursue further. It was a general problem as to whether access was to be made available to all, gentry and country folk alike. At a beach, there was more room; at a well or spring, much more contact and conflict. The seaside threw up real tension between social groups and classes over the proper conventions of bathing dress and behaviour; and over mixed bathing, which at the more select resorts was resolved by a separation of the sexes either by time or place. The solution at Moffat was to fence the springs and build a small house where the waters were served, with a reduced charge to the poor, and to provide separate covered apartments for ladies and gentlemen to which "none of the lower people were to be admitted". ${ }^{60}$

\footnotetext{
${ }^{57}$ George Milligen, An account of the vertues and use of the mineral waters near Moffat, Edinburgh, 1733.

${ }^{58}$ The statistical account of Scotland, 1792, op. cit., note 46 above, 'The Parish of Moffat, mineral springs', vol. 2, pp. 296-7.
} 
The spas had an additional problem; the need to separate users by complaint, as well as by gender and class. Some objected - understandably - to sharing bath waters with people whose skin complaints or fevers might be contagious. If a spa had more than one spring, then the users could be spread and segregated, which is again what happened at Moffat. Having several springs or wells, and of differing kinds, at a considerable distance apart-over a mile-helped to boost visitor numbers, as, to some extent, patients could be segregated during their treatments. The formula seems to have worked. David Allan's watercolours of Moffat (executed in 1795) show several well-dressed individuals at the wellhouse; one being served with his draught, another quaffing his glass, a third having his leg washed, and half-a-dozen parties walking nearby. Moffat spa was a reasonable success, if in no way able to match any of the leading English spas. On his visit in April 1805, one visitor found no fewer than 250 invalids come "to drink a mineral water"61 (and drink the goats' whey). This was a sizeable contingent to entertain and accommodate for a village of perhaps only 1200, although in absolute numbers well behind what the English spa resorts such as Harrogate could muster. Here long-stay visitors were counted not merely in dozens and scores, but in four figures. ${ }^{62}$

An account of particular significance is that of Dr Thomas Garnett, originally from Cumberland, who had served an apprenticeship with a Yorkshire surgeon before matriculating at Edinburgh where he graduated MD in $1786 .{ }^{63}$ Combining his scientific interests (he wrote the entry on "optics" for the Encyclopaedia Britannica) with a medical practice, he had become a professor of natural philosophy at the Andersonian Institute in Glasgow, and from there spent the summer (a three weeks' residence) of 1797 at Moffat with his family. He already had some reputation for spa water evaluation, having some years earlier, while in medical practice, assessed the waters at Harley Green near Halifax, Harrogate and a number of Yorkshire spas. ${ }^{64}$ His findings at Moffat were published both as a pamphlet and incorporated into a lengthier work, Observations on a tour through the Highlands and part of the Western Isles of Scotland, which appeared in 1800. While the clientele were from Lowland Scotland-Edinburgh, Glasgow and Dumfries-he noted that the water was being bottled for export to other parts of Britain and even to the West Indies as a medicinal agent. His analysis found the waters to be very similar to those he had analysed in Yorkshire, though perhaps not quite as strong, and he quoted with approval the report to him from a veteran local doctor, a Doctor Johnstone, as to the effects of these waters: very good in scrofulous, scurvy and rheumatism cases, so gentle in their operation that the most delicate could use them with great safety

\footnotetext{
${ }^{61} \mathrm{~J}$ Mawman, An excursion to the Highlands of Scotland and the English lakes, London, Poultrey, 1805, p. 195.

${ }^{62}$ Granville, op. cit., note 16 above, vol.1, p. 61 .

${ }^{63}$ 'Thomas Garnett, 1766-1802', Dictionary of National Biography, London, Smith, Elder, 1908, vol. 7, pp. 886-7.

${ }^{64}$ Thomas Garnett, Treatise on the mineral waters of Harrogate: containing the history of
}

these waters, their chemical analysis, medicinal properties, and plain directions for their use, London, Leeds and Bradford, 1792, and Harley Green near Halifax, Bradford, 1790; Saunders, op. cit., note 32 above, p. 322, cites Garnett's work at both Harrogate and Moffat with approval. 


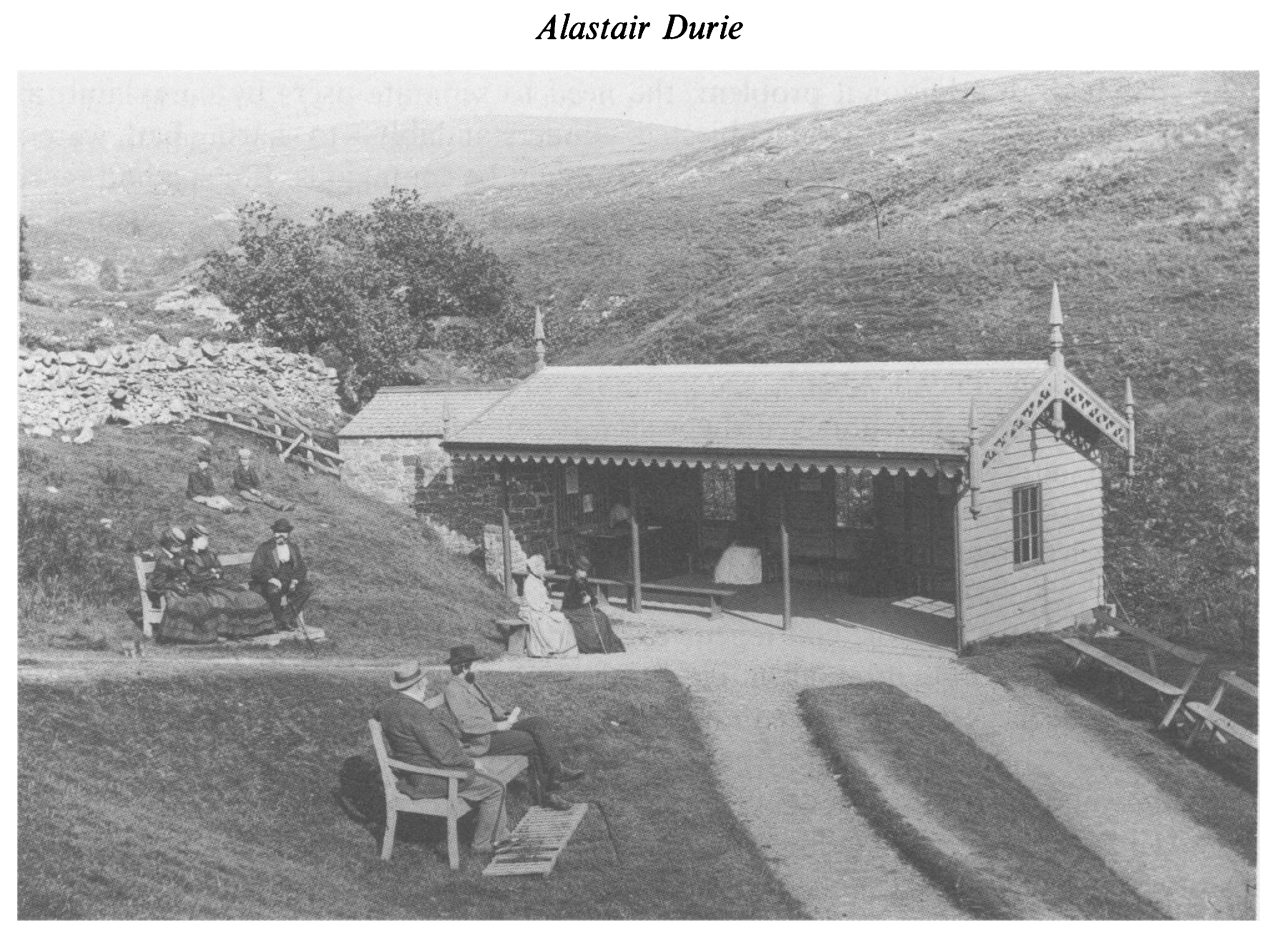

Figure 3: A view taken by the Aberdeen photographer George Washington Wilson $c .1870$ of the modest well-house at Moffat with various patrons resting after their morning constitutional to take their prescribed quota of spring water. (By kind permission of Aberdeen University Library.)

and benefit. ${ }^{65}$ Reprinted several times, and translated into German, Garnett's work may well have reached a wider audience than conventional specialist or local literature. Moffat, therefore, better known than any other spa north of the Border, was a success story by the admittedly modest standards of Scottish spas, and maintained its position throughout the nineteenth century. Like Strathpeffer and Bridge of Allan, it owed much to the patronage of local landowners and to the endorsement of the virtues of its springs by figures of medical and scientific standing. Location and access were issues of relevance, but distance alone, it seems, as Strathpeffer was to show, was no bar if the other variables of good waters, patronage and amenities were in place.

Although neither was to make much of mark after c. 1830, Pannanich and Peterhead were to the fore in the later eighteenth century. Pannanich, near Ballater,

\footnotetext{
${ }^{65}$ Thomas Garnett, Observations on a tour through the Highlands and part of the Western Isles of Scotland, 2nd ed., 2 vols, London, John Stockdale, 1811, pp. 252-5. Johnstone asserted
}

that while the standard morning prescription was one to three bottles drunk each morning at the well, it was very common amongst the lower class to drink from three to six, and some five to eight. 
was a minor inland spa, whose waters were discovered in familiar fashion by an old woman in 1760. It did threaten to break into the top division, but somehow never quite achieved recognition. The area, as elsewhere in Scotland-Dunkeld, Moffat, Arran-had attracted colonies of convalescents who came for the "goat's milk" and the fresh air, but the Pannanich wells did command some attention. Thomas Pennant in his influential Tour in Scotland (first edition 1769) highlighted the reputation of its waters for the treatment of rheumatic and scrofulous cases. It was, according to him, attracting a numerous summer clientele, for whose reception "several commodious houses have been built". ${ }^{66}$ In December 1781, a correspondent, "Aquaticus", supplied the local paper at Aberdeen with a list of those who had been at Pannanich over the summer "to use the waters for their health" ${ }^{67}$ The sixty-seven names, of which more than half were female, were headed by Lady Peterborough and Lady Harriet Gordon. Most of the addresses given were in the north-east, but two were colonial (India and Jamaica), and there was a Dr Hughes from London. The local landowners, the Farquharsons of Monaltry, had given consistent support. ${ }^{68}$ They had improved the roads in the vicinity, cleared out the springs, of which there were three, built a wellhouse with a public and private bath, erected an octagon for the better sort to retire to, and several houses for the poor, and had been responsible for the construction of a large lodge (Pannanich House) to act as high-class accommodation. ${ }^{69}$ It is said that the spa was first established by Francis Farquharson of Monaltrie (who had been captured at Culloden and kept on parole in England at Berkhamstead for nearly twenty years) in order to receive his Jacobite friends. ${ }^{70}$ A poem of 1782 saluted him: "patron of this distinguished vale, Hygeia's priest, Monaltrie hail". His nephew, William, carried on the programme of development, with some success. "It is much resorted to by the country people, and by several persons of the middle rank of life." "11 The Aberdeen Journal reported in August 1824 that Ballater, Pannanich and everywhere around was crammed with visitors (over 500), that the waters of Pannanich were very plentiful, and such was the demand for this "salubrious beverage that the proprietor deemed it necessary to make a moderate charge for the use of the wells" ${ }^{72}$ Clearly some benefited from their time there; John Ogilvie, a teacher and lexicographer, enthused about Pannanich to which he was a frequent visitor in the 1830 s.

\footnotetext{
${ }^{66}$ Thomas Pennant, $A$ tour in Scotland, Warrington, W Eyres, 1769, p.119. Pennant also describes the waters at Moffat, "a neat small town, famous for its spas".

${ }^{67}$ Aberdeen Journal, 31 Dec. 1781, p. 4.

${ }^{68}$ The statistical account of Scotland, 1794, op. cit., note 36 above, 'Parish of Glenmuick', vol. 12 , pp. $222-4$.

${ }_{69}$ Aberdeen Journal, 23 April 1781, p. 4, carried an advertisement from Archibald Abel, who had just leased the House of Pannanich "for the purpose of accommodating those who chose
}

to attend the wells with Lodgings and Entertainment. The House is perfectly dry, and the Furniture, particularly the beds extremely good."

${ }^{70}$ A A Cormack, Two Aberdeenshire spas: Peterhead and Pannanich, Aberdeen University Press, 1962, p. 18.

${ }^{71} \mathrm{G} S \mathrm{~S}$ Keith, $A$ general view of the agriculture of Aberdeenshire, Aberdeen, D Chalmers for A Brown, 1811, 'Of mineral waters, or springs', p. 74.

${ }^{72}$ Aberdeen Journal, 18 Aug. 1824, p. 3. 


\section{Alastair Durie}

I've seen the sick to health return, I've seen the sad forget to mourn, I've seen the lame their crutches burn, And loup and fling at Pannanich.

I've seen the auld seem young and frisky, Without the aid of ale or whisky, I've seen the dullest hearts grow brisky, At blithesome, healthful Pannanich. ${ }^{73}$

The Abridged statistical history of Scotland in 1853 called it the most fashionable watering place in the north of Scotland, and anticipated that the coming of the Deeside Railway would lead to further growth. ${ }^{74}$ But in fact it seems to have gone only into rapid decline; Royal Deeside flourished, but not the spa. When Queen Victoria visited Pannanich in October 1870, she did actually taste the water, "strongly impregnated with iron" and looked at the humble but very clean accommodation in the curious little old inn, "which used to be much frequented" (my italics). ${ }^{75}$

\section{The Role of the Medical Promoter: Troup and Pannanich}

Important to the rise of Pannanich in the later eighteenth century was the role played by a local doctor, Jonathan Troup (MA, Marischal College, 1786) ${ }^{76}$ Troup, of Aberdeenshire stock, who was practising in the locality, started to advertise in the early 1790s that he would attend at the wells every week during the season, from 10 June to the end of August. Perhaps prompted by the active promotion then current of Peterhead's mineral waters and sea-bathing, in June 1794 Troup took out a full page advertisement in the Aberdeen Journal, in which he laid out a series of guidelines for the proper use of the water at Pannanich. He stressed that indiscriminate and fitful use was of no value, and indeed dangerous, a moral that he drove home with two cases. The water was too strong for the very young or the very old and infirm, not effective for sore eyes but useful for the treatment of gravel and of skin complaints, and so on. An essential part of recovery was exercise, the air about Pannanich being the purest in Scotland. A fleeting visit was of no service: the longer the stay, the more the benefit.

Many people think, if they drink the water for two or three days, that they are relieved, and off they go, cured as if by a charm: but they soon find a return of their complaints. The water will have little effect unless continued a month or six weeks, and drunk early in the morning on an empty stomach. ${ }^{77}$

Spa doctors everywhere would have echoed this advice, given on medical grounds, but also with an eye to the financial benefit from long-stay visitors.

\footnotetext{
${ }^{73}$ Cormack, op. cit., note 70 above, p. 54.

${ }^{74} \mathrm{~J} \mathrm{H}$ Dawson, An abridged statistical history of Scotland, Edinburgh, W H Lizars, 1853, p. 31.

${ }^{75}$ Queen Victoria, More leaves from the journal of a life in the Highlands, 2nd ed., London, Smith, Elder, 1884, pp. 150-1.
} 
Peterhead was another centre of spa treatment in the north-east where medical involvement proved important. The so-called Wine Well had long had a reputation and was much used by "country people", who came in such numbers, or so a description in 1795 averred, from a radius of up to thirty or forty miles, that the well was sometimes drunk dry by later in the day $!^{78}$ Peterhead was unusual in the Scottish context in that it came to combine the older mineral water therapies with the new regime of the salt-water cure, as was the case at Scarborough. In the 1770s and 1780s, George Carnegie was a regular visitor there, and frequently reported on the benefits of his times at Peterhead: "I doubt not", he told his wife in July 1777, "the Bathing and Watter drinking will have their usual wonted good Effects". ${ }^{9}$ Scotland had very few such places, although there was something similar at Fraserburgh: Brow on the Solway was an insignificant trickle of a spring and a muddy bathing station. But Peterhead was on a much grander scale, with sea-bathing and water drinking firmly established by the mid-1770s, ${ }^{80}$ and probably rather earlier. A problem was the bleakness of the shore, which either deterred potential visitors or led them to bathe only with understandable reluctance. The solution was to be covered baths filled with cold sea water which-along with changing accommodation and other amenities-were built in 1762 by the town's Freemasons "at the desire and by the direction of the most eminent physicians" ${ }^{81}$ This initiative of the local Masonic lodge was not an altruistic but a revenue-generating venture, which suggests that demand was already proven. The baths were not ideal; patrons objected to the rather claustrophobic narrowness of what were but pits, and some did not like using the same water as others before them. Accordingly, much to the irritation of the masons, a much larger open-air pool, cut out of the rockline at the shore, was created in about 1800 by a druggist, Mr Arbuthnott. This combined the "advantages of house-bathing with those of open sea-bathing" ${ }^{\prime 2}$ there being separate hours for ladies and gentlemen. It proved so popular that another bath was built for men only. Arbuthnot also added warm salt-water baths.

\section{Clergymen and Spa Promotion: Moir and Laing at Peterhead}

As elsewhere, the role of local clergymen with medical interests was significant in Peterhead's heyday. Two in particular stand out. The Rev. George Moir, was presented by Marischal College at Aberdeen with a Doctorate of Medicine in 1765

\footnotetext{
${ }^{78}$ The statistical account of Scotland, ed. Sir John Sinclair, Edinburgh, William Creech, 1795, 'Parish of Peterhead', vol. 16, p. 605; "servants frequently make it an article in their agreements with their masters to have 5 or 6 days of the Wine Well at Peterhead whether they need it or not".

${ }^{79}$ Cormack, op. cit., note 70 above, p. 27.

${ }^{80}$ Aberdeen Journal carried on 17 July 1775 , p. 4, "a list of the Company who have arrived at Peterhead this Season to bathe and drink the Waters".
}

\footnotetext{
${ }^{81}$ This section draws on William Laing's two works, An account of Peterhead: its mineral well, air, and neighbourhood, London, T Evans, 1793, and An account of the new cold and warm sea baths at Peterhead, Aberdeen, J Chalmers, 1804. The quotation is from Aberdeen Journal, 14 June 1762 , cited in Cormack, op. cit., note 70 above, p. 17.

${ }^{82}$ Laing, Account of the ... baths at Peterhead, op. cit., note 81 above, p. 5 .
} 


\section{Alastair Durie}

"that he might augment his income by advising sick visitors". ${ }^{83}$ Moir's informed advice was sought by those at the spa on what regime to follow, whether the mineral water treatments or the sea-bathing, and what combination was most suitable. On occasion, he either recommended alternative treatments or even sent the patients home, "with advice to take such medicines as seem most proper for them" ${ }^{84}$ The second was the Rev. William Laing, minister of the Episcopal Chapel, with whom Moir did not always agree on either theological or medical matters. He too obtained an MD from Marischal in 1782. Laing was yet another Scottish minister to see medical work as part of his pastoral responsibilities. How far he had had any formal medical training is undetermined, but his writing makes clear that he was familiar with a wide range of relevant literature such as Dr Thomas Reid's Directions for warm and cold sea-bathing. ${ }^{85} \mathrm{He}$ was equally experienced in the appropriate technology for scientific work including Nooth's apparatus; the tin retort rather than the Florence flask and bladder. His Account of Peterhead: its mineral well, air, and neighbourhood, published in London in 1793, is a substantial 79-page pamphlet which reviews what the waters had to offer. Laing emphasized that they were more effectual for some complaints than for others, and allowed, as some critics including Sir Walter Scott ${ }^{86}$ alleged, that the exercise, air and company to be found were as important as the treatment.

How can a person fail to eat a hearty breakfast ... who rises before six in the morning, invigorates himself by the cold sea bath, washes his stomach with such a quantity of water, were it no other than common water, and walks about in the open air till nine o'clock? And if he repeat the same ablution of the stomach from eleven to twelve, walk, sail or ride from that time to three, no wonder if he have a fresh appetite for dinner. If he dine in a large company of well-bred persons, wishing to please and to be pleased, enjoy two hours of enlivening free conversation; if he meet a party of friends at tea in the house of some of the ladies or drink tea in public, and partake of a public dance, and if after a light supper, he go early to bed; what wonder is it if cheerfulness, sound sleep, and forgetfulness of care be the consequence; and if continuance of a similar plan for several weeks be followed by an increase of health, of spirits, and constitution. Far be it from me to dent the good effects of these things. On the contrary I have seen them often with pleasure ... but let it be allowed in the first place that the well has the merit of collecting together all these advantages. ${ }^{87}$

Laing also included a full account of the regime and routine at Peterhead.

The Mineral Well is contained in a small reservoir of stone, situated at the end of an oblong enclosed space; round which are seats of freestone for the accommodation of such as choose to drink the water in the open air. Adjoining to this space is the Mason-Lodge, in the lower story of which are the water room, and the baths. The water (or pump room) is constantly attended, at all the hours of drinking the water by a decent, cleanly, attentive, elderly woman,

${ }^{83}$ Cormack, op. cit., note 70 above, p. 23.

${ }^{84}$ The statistical account of Scotland, 1795, op. cit., note 78 above, 'Parish of Peterhead', vol. 16, p. 605 .

${ }^{85}$ Laing, An account of Peterhead, op. cit., note 81 above, p. 32; Dr Thomas Reid, Directions for warm and cold sea-bathing, Dublin, printed by William Gilbert, 1795.

\footnotetext{
${ }^{86}$ Scott, op. cit., note 43 above, Introduction (dated 1 Feb. 1832), p. viii: “The invalid often finds relief from his complaints, less because of the healing virtues of the spa itself than because his system of ordinary life undergoes an entire change."

${ }^{87}$ Laing, An account of Peterhead, op. cit., note 81 above, p. 29.
} 


\section{Spa and Seaside Resorts in Scotland c. 1750-1830}

who keeps the well in good order, serves the company with water, orders fires in the rooms when cold or rainy weather makes it necessary, and assists the ladies in bathing; and who has her living from the gratuities given by the well-company for these services ... there is a large hall, of which the company have the use for dancing and sometimes for a tea-room. The dues for the pump room and bath are, a crown for the former, and a guinea for the latter during the season, or a shilling for each time of bathing. The dining room is a large hall which has on many occasions contained near sixty persons at dinner. The company are all accommodated in private lodgings through the town, which are let at a very reasonable rate per week. ${ }^{88}$

There was, therefore, some justice in the claim that by the early nineteenth century Peterhead was as well-equipped as any coastal health resort in Scotland. "The place is gay" was Buchan's assessment. ${ }^{89}$ Portobello, with its better beach, might have challenged it, and had a much larger population on which to draw, but for some reason, failed to make anything of a strong chalybeate spring in the locality. Thomas Thomson, for one, considered this a curious lapse. Yet Peterhead did fade; "of late years it has lost its celebrity", was Thomson's comment in $1828 .{ }^{90}$ A growing shortfall in the flow of water at the well may have been the root, or at least part, of the problem-one which was not unknown elsewhere-or better steamship services perhaps drew health seekers away to warmer climes.

\section{Health Resorts of Limited Reputation and Appeal}

The fact remains, however, that in the long run Peterhead did not prosper. It was no Scottish Scarborough any more than Moffat was the Harrogate of north Britain. Nor indeed did any Scottish spa or seaside resort in the period 1730-1830 achieve the levels of development and recognition of their southern counterparts. Perhaps it was unrealistic to expect them to do so; after all, the Irish had even less success. Was it the problems of climate and distance, or the quality of the mineral waters? It cannot have been the standing and credentials of those medical and scientific authorities who endorsed the value of the Scottish waters. A factor may have been the inability of the Scots to make their spas select, to attract and retain the highspending clientele of the English resorts. But did they want to? On both practical and moral grounds, it was difficult to exclude the "country people" and the "poor" from waters that were perceived to be health-giving. And the setters of tone in Scottish society were none too sure about the some of the features of spa society in the South and on the Continent that appealed to a moneyed clientele. The cultural dimension features large in Wade's diagnosis.

The [Scottish watering places] are but in the infancy of their fame and estimation; the latter [the English] have been long in vogue; the former have but a limited population on which to draw for visitors; the latter are, by a more than quintuple population to that of Scotland supplied in abundance. The former receive ... but a carefully allocated portion of moderate incomes: the latter are often chosen by the opulent and dissipated. ${ }^{91}$

\footnotetext{
${ }^{88}$ Ibid., p. 58.

${ }^{89}$ Buchan, op. cit., note 37 above, p. 688.

${ }^{90}$ Professor Thomas Thomson, 'On the mineral waters of Scotland', Glasgow med. J.,
}

1828, 1: 130-1, 126. I am grateful to Valerie McClure of the Library of Royal College of Physicians at Glasgow for this reference.

${ }^{91}$ Wade, op. cit., note 47 above, p. 295. 


\section{Alastair Durie}

What held Scottish watering places of all kinds back, Wade argued, was that their respectability made them dull, an assessment that Professor the Rev. John Walker, minister at Moffat some sixty years previously, would have found all too familiar. ${ }^{92}$ A similar judgement was made about the Irish spas by Neville Wood; they suffered, he said from "the impression that they were dull". ${ }^{93}$ Spencer Thomson blamed the failure of the Scottish spas on "fashion, climate and the absence of mineral waters", ${ }^{94}$ a rather too sweeping dismissal of the claims of the Scottish spa waters. Yet the failure to match the success of other countries does seem to underline that what made for a successful health resort was not just the virtue of the waters or the calibre of the care and cure, but the context and culture. Strong recommendations by satisfied visitors and endorsement by medical authorities were essential, but not sufficient to guarantee commercial success. As this study has shown, despite all the starts made in Scotland, for whatever reason, none of the Scottish spas really achieved the kind of momentum that would let them break out from the initial phase of small-scale speculative development to the consolidatory accumulation of amenities and reputation based on established demand of substance. They remained, with the solitary exception of Strathpeffer, mostly of minor significance, despite rising demand, in a market dominated by the spa resorts of the Continent. Marienburg and Mentone were the preferred destinations for health, agreed most authorities. Moffat was only a fallback resort, if time or money were short. The Scottish seaside did establish itself with all classes of society, with some coastal resorts along the Firths of Clyde and Forth attracting a mass clientele, and others a more select patronage. But although the health and the seaside were indissolubly linked in the popular mind, the appeal was no longer narrowly therapeutic.

\footnotetext{
${ }^{92}$ John Walker was minister at Moffat from June 1762, and, despite his appointment to the regius chair of natural history at the University of Edinburgh in June 1779, retained his charge at Moffat for a further three and a half years until he was transferred to Coleston, a parish on the outskirts of Edinburgh.
}

\footnotetext{
${ }^{93}$ Neville Wood, The health resorts of the British islands, University of London Press, 1912, p. 225.

${ }^{94}$ Spencer Thomson, The health resorts of Britain and how to profit by them, London, Ward \& Lock, 1860, pp. 297-8. "Scotland is not a place of health resorts after the manner of England".
} 